ELORE (ISSN 1456-3010), vol. $16-1 / 2009$.

Julkaisija: Suomen Kansantietouden Tutkijain Seura ry.

[http://www.elore.fi/arkisto/1_09/kirjat_saarikoski_01_09.pdf]

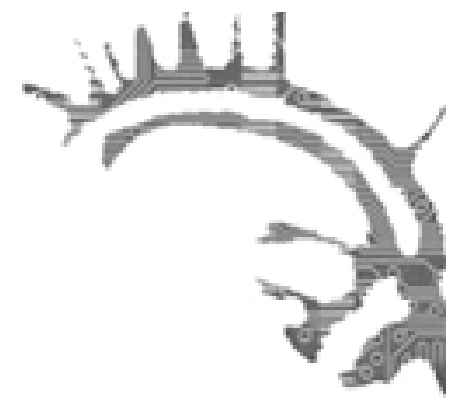

KIRJA-ARVIO:

\title{
FOLKLORISTIIKASTA LEVEÄLLÄ RINTAMALLA
}

Knunttila, Seppo 2008: Entinen aika, nykyinen mieli. Toimittaneet Ulla Piela ja Sinikka Vakimo. Suomalaisen Kirjallisunden Seuran Toimituksia 1185, Tiede. Helsinki: SKS. 550 sivua.

\section{$\underline{\text { Helena Saarikoski }}$}

Professori Seppo Knuuttilan kuusikymmenvuotispäiväksi julkaistu juhlakirja on hänen kirjoituksistaan lähes kolmenkymmenen vuoden ajalta koottu tiiliskivi. Päivänsankarin omista kirjoituksista kootut juhlakirjat, kuten esimerkiksi Auli Hakulisen (2001) ja Pentti Leinonkin (2002) kirjat, ovat antoisia läpileikkauksia paljon tehneiden ja paljoon vaikuttaneiden tutkijoiden työhön. Knuuttilan kirjassa on 42 kirjoitusta, jotka toimittajat ovat jakaneet seitsemään väljään osioon kirjoittajan mielenkiinnon suuntien mukaan. Mentaliteetin tutkimus, perinteen merkitys, huumorintutkimus, muistitiedon tutkimus, kansanomaisen taiteen ja estetiikan tutkimus, populaarikulttuurin tutkimus sekä lopuksi tieteenalaa luotaavat kirjoitukset ovat saaneet omat osastonsa kirjassa. Kuhunkin osioon on valikoitu tasaisesti viidestä seitsemään kirjoitusta eri ajoilta. Lisäksi kirjassa on kirjoitusten yhteinen lähdeluettelo, henkilöhakemisto ja Seppo Knuuttilan vuodet 1974-2007 kattava bibliografia, jonka on koonnut Kristiina Näyhö.

\section{TEKSTIEN RUNSAUdESTA YKSIIN KANSIIN}

Juhlakirjaan on koottu paljon sellaisia kirjoituksia, jotka ovat ilmestyneet harvinaisissa erikoisteoksissa tai vain englanniksi ja jotka todella ansaitsevat tulla huomatuiksi ja lukijan helposti tavoitettaviksi kirjassa. Kirjoitusten ajoitukseen liittyy vakavin puutos, joka heikentää muuten kätevän "paketin" käyttökelpoisuutta. Kirjoitusten alkuperäiset ilmestymispaikat ja -vuodet eivät ole missään kootusti näkyvillä, eivätkä kirjoitukset ole aikajärjestyksessä. Esimerkiksi huumorintutkimuksen osiossa "Ei nauruja jos ei huimia" kirjoitukset ovat ilmestyneet, tässä järjestyksessä, vuosina 1979, 1981, 2001, 


\section{FOLKLORISTIIKASTA LEVEÄLL̈̈̈ RINTAMALLA}

1984, 1996, 2001 ja 1990 (kunkin kirjoituksen lopusta poimittujen tietojen mukaan). Jos kirjaa lukee alusta loppuun, on vaikea seurata kirjoittajan ajattelun kehittymistä. Hän joutuu nyt kirjassa ikään kuin yhtä lailla seisomaan kaiken kolmen vuosikymmenen aikana kirjoittamansa takana. Toisaalta Seppo Knuuttilalla sekä aiheet että näkökulmat ovat hyvin vaihtelevia. Kirjassa ei ole sillä tavalla kahta samanaiheista kirjoitusta, että jotakin nimenomaista ajattelumuutosta voisikaan ehkä huomata. Kirjaa ei ole sitä paitsi tarpeen lukea alusta loppuun. Se on kuin karjalainen pitopöytä tai ruotsinlaivan seisova pöytä, josta jokainen voi ottaa haluamiaan eväitä annoksen kerrallaan mistä kohtaa mielii.

Poikkeuksena on kirjan viimeinen osio, "Tutkimuksen suunnanmuutoksia", jonka kuusi kirjoitusta ovat aikajärjestyksessä vuosilta 1982-2008. Viimeisenä on ainoa aiemmin julkaisematon kirjoitus, "Kulttuurintutkimuksen muistilista" (s. 487-499), joka on koottu kirjaa varten Seppo Knuuttilan kolmesta loppupuheenvuorosta Kulttuurintutkimuksen päivillä (Metodit 2003, Kontekstit 2005 ja Aineistot 2007). Viimeinen osio on kirjan ehdottomasti raskain ja myös pisin, siinä määrin, että kirjaa uhkaa melkoinen ahteripaino, vaikka Knuuttilan keskeisin ja monen mielestä ehkä tärkein tutkimusalue, kansanomainen mentaliteetti, on sijoitettu ensimmäiseksi osioksi ja "Perinteen painovoima" -niminen osio sen jälkeen. Viimeisen osion kirjoitukset ovat tiukkoja analyyseja tieteenalan tilasta, oppihistoriallisia katsauksia ja tutkimuspoliittisia kannanottoja. Muualla kirjassa kirjoitukset ovat enimmäkseen lyhyitä ja kepeitä, tutkimuksellisia lastuja, jotka ovat helppoja ja hauskoja lukea, vaikka niissä olisi paljon asiaa.

Kirjoitusten käytännönläheisyys vaihtelee. Toiset lähtevät liikkeelle kirjoittajan omista kokemuksista tai joistakin tarkoin valikoiduista aineistoesimerkeistä, joita sitten avataan ja eritellään tutkimuskysymysten valossa. Osa kirjoituksista liikkuu yleisemmällä tasolla teoreettisempia keskusteluja ja kysymyksiä pohtien. Knuuttila on hyvä kirjoittaja kaikenlaisissa teksteissä. Ehkä omimmillaan hän on kuitenkin ensin mainitun kaltaisissa pyrähdyksissä, lyhyehköissä teksteissä, joista esimerkiksi voi poimia alun perin Eloressa 2/2001 julkaistun kirjoituksen "Syödäkö vai eikö olla? Kertomukset ja kuvitelmat ihmissyönnistä kulttuurisina moraalikoodeina" (s. 158-168). Kirjoituksen kohteena on äärimmäisen käsittely huumorin keinoin. Toinen esimerkki on nimiessee "Entinen aika ja nykyinen mieli" (s. 238-243), joka lähtee kirjoittajan lapsuuden- ja nuoruudenkokemuksista, esittelee kaksi käsitettä tai ilmiötä, historiallisen inversion ja ajan valituksen, ja päätyy eräiden tutkimukseenkin vaikuttaneiden piiloisten konservatiivis-populististen keinojen paljastamiseen. Tyypillisesti Knuuttilan tutkimuslastuja luonnehtii kiinteästi muotoiltu ja suppea keskeisidea, jonka varaan juttu on rakennettu muutamin aineistoesimerkein ja valituin tutkimusmallein. Kirjoituksesta muodostuu jotenkin kattava probleemin käsittely, joka parhaissa tapauksissa avaa laajoja näköaloja tai syviä kannanottoja. Suurin osa kirjaan valituista kirjoituksista on tätä parasta viiden tähden luokkaa.

Entinen aika, nykyinen mieli piirtää kuvan kirjoittajastaan laajalti lukeneena ja sivistyneenä vasemmistointellektuellina pikemmin kuin kovana tiedemiehenä (merkityksessä science). Se pukee kyllä humanistiprofessoria. Maailmaa ei jäsennetä formaalein operaatioin vaan sanoin, lausein, tekstein. 
Seppo Knuuttilan bibliografiaa silmäilemällä muodostuu käsitys erittäin ahkerasta ja moniaalle kiinnostuvasta kirjoittajasta. Samalla juhlakirjan valikoima vaikuttaa edustavalta siinä mielessä, että Knuuttilan tuotannon valtamäärä näyttää koostuvan lyhyehköistä tutkimusesseistä. Itse kunkin suosikkiteksti saattaa tietenkin puuttua juuri tästä valikoimasta. Täyspitkiä tutkimusartikkeleita ei ole juhlakirjaan mahdutettu monta. Toimittajat ovat tehneet kelpo työn luodessaan kirjoitusten osiojaottelun, joka auttaa myös bibliografian hahmottamisessa aihepiireihin. Kun Knuuttila ei ole väitöskirjaansa (1992) lukuun ottamatta juuri julkaissut laajoja erillistutkimuksia, juhlakirjan rinnalle alkaa toivoa temaattisia artikkelikokoelmia, vaikka kirjan seitsemän osion mukaan, joissa voisi yksissä kansissa kootusti tutustua hänen tiettyä aihepiiriä koskevaan tutkimukseensa. Juhlakirjan kunnioitettavasta volyymista huolimatta kaikkia seitsemää ei lyödä yhdellä iskulla.

\section{Pisteen alaa lajemmalta}

Tällä hetkellä Suomessa pyritään erittäin voimakkaasti legitimoimaan ja institutioimaan folkloristiikasta sellaista eksklusiivista määritelmää, jonka mukaan Seppo Knuuttilan tutkimus ei ole lainkaan folkloristiikkaa. Folklore nimittäin ei ole hänen varsinainen tutkimuskohteensa vaan lähteensä muiden, tarkkaan ottaen folkloren ulkopuolisten asioiden kuten maailmankuvan tai mentaliteetin tutkimuksessa. Knuuttila väittää, että viimemainitut olisivat folkloristiikan "keskeisiä tutkimuskohteita", joita folklore "heijastaa" ja joita folkloristiikka ei pysty tyhjentävästi selittämään trivialisoimatta itseään ja että tämä olisi jopa folkloristiikkaa tieteenä elossa pitävä ongelma (s. 60). Mainitun määrittelyvallan pyrkimyksen valossa tällaiset tieteenalan perustoja koskevat pinnalta neutraalit väitteet näyttäytyvät akuutisti ja painavasti poliittisina.

Seppo Knuuttilan professuurin opetusala on folkloristiikka, samoin kuin parin muun kansanomaisen ajattelun tai kulttuurin tutkijan, ja folkloristiikan dosenteillakin on yliopistossa omat oppituolinsa määriteltävinään. Mutta hämmästyttävän paljon harvemmassa ovat ne todelliset folkloristit, jotka mahtuvat folkloristiikan nykyiselle "painopisteen alalle". Pelkään, että jos folkloristiikan annetaan jatkaa itsensä määrittelyä ekskluusion menetelmällä, tieteenala on vaarassa supistaa itsensä olemattomiin. Jopa yksi maamme neljästä folkloristiikan professorista on jo tällä menetelmällä määritelty tieteenalan ulkopuolelle. Folkloristeilla kansanomaisen fantasiamaailman tuntijoina voi tietenkin olla taipumusta rakentaa linnoituksensa mahdottomuuskuviin, "pisteen alalle". Knuuttila ei ole omaksunut tätä après moi le déluge -ajattelua, vai pitäisikö puhua divide et impera -ajattelusta, vaan yrittää luoda folkloristiikalle rakentavampia tulevaisuuden vaihtoehtoja.

Knuuttilan strategiana on liittyä empimättä uuteen "kulttuurintutkimukseen" ja pyrkiä ottamaan folkloristiikalle jonkinlainen johtoasemakin tällä periaatteessa kyllä monitieteisellä, mutta yhteiskuntatieteilijöiden silkalla massan ylivoimalla paikoin jopa aggressiivisesti dominoimalla alalla. Kulttuuriantropologi Clifford Geertzin (2000) 
kertoman vertauskuvan mukaan elefantista ja jäniksestä keitetään Cultural Studies -keitto, ja elefantti pelkää henkensä edestä, että jäniksen maku suorastaan peittää hänen hienon arominsa. Kun elefantti pelkää henkensä edestä, jäniksellä on tunnetut keinonsa, mutta hän saa olla aika veijari käyttämään keinojaan. Veijarin kuria ei puutu Seppo Knuuttilalta.

\section{KirjallisuUs}

GEERTZ, CLIFFORD 2000: Available Light. Anthropological Reflections on Philosophical Topics. Princeton: Princeton University Press.

HAKULINEN, AULI 2001: Lukemisto. Kirjoituksia kolmelta vuosikymmeneltä. [Toimittaneet Lea Laitinen et al.] Helsinki: SKS.

KNUUTTILA, SEPPO 1992: Kansanbuumorin mieli. Kaskut maailmankuvan aineksena. Helsinki: SKS.

LEINO, PENTTI 2002: Mittoja, muotoja, merkitykesiä. [Toimittaneet Liisa Tainio et al.] Helsinki: SKS.

Filosofian tohtori Helena Saarikoski on folkloristiikan dosentti Helsingin yliopistossa ja toimii naistutkimuksen erikoistutkijana Turun yliopistossa. 